Iwona KOMORSKA*

\title{
AUTOMOBILE GEARBOX DIAGNOSTICS ON THE BASIS OF THE REFERENCE MODEL
}

\begin{abstract}
SUMMARY
A method of diagnostics of the automobile gearbox wearing out is presented in this paper. The procedure can be automatically realised during driving. To be able to perform such diagnostics the reference model of the vibration signal on the basis of the synchronously averaged signal was created for a new gearbox (in a good technical condition). In order to realize the procedure on-board this model must be easily identifiable. A complicated structural model was given up for the simpler model of the abstract vibrations signal. Three ways of modelling were presented: harmonic series, parametric ARMA (Auto Regressive Moving Average) model, and the wavelet model. The current vibration signal is recorded at the determined moment of driving and then compared with the reference model. After each overhaul or exchange of drive system elements the reference model should be identified again. Diagnostics is being done by comparing measures for the reference model and the currently measured adequately processed - signal. The method was verified in the active experiment performed on the Fiat Punto automobile with a 5-speed gearbox. The described method can constitute the supplementation of on-board automobile system by the mechanical failures of the drive system. This procedure can be broadened by defects of the main gear, differential gear, articulated joints, bearing, engine exhaust valves, and engine head gasket.
\end{abstract}

Keywords: diagnostic model, vibration acceleration signal, gearbox wear, on-board diagnostics, model identification

\section{DIAGNOZOWANIE SKRZYNI BIEGÓW W SAMOCHODZIE NA PODSTAWIE MODELU REFERENCYJNEGO}

$W$ artykule przedstawiono metode diagnozowania zużycia samochodowej skrzyni biegów. Procedura realizowana może być automatycznie podczas jazdy samochodu. W tym celu dla nowej skrzyni ( $w$ dobrym stanie technicznym) tworzony jest model referencyjny sygnatu drgań, na bazie sygnatu uśrednionego synchronicznie. Aby procedura mogla być realizowana on-board, model musi być tatwo identyfikowalny. Zrezygnowano ze skomplikowanego modelu strukturalnego obiektu na rzecz prostszego modelu abstrakcyjnego sygnatu drgań. Przedstawiono trzy sposoby modelowania: ciag harmonicznych, model parametryczny ARMA i model falkowy. Bieżacy sygnat drgań jest rejestrowany $w$ określonym momencie jazdy, a następnie porównywany z modelem referencyjnym. Po każdym remoncie lub wymianie elementów zespotu napędowego model referencyjny powinien być identyfikowany od nowa. Diagnozowanie nastęuje przez porównanie miar dla modelu bazowego i sygnatu mierzonego na bieżaco oraz odpowiednio przetworzonego. Metoda została zweryfikowana w eksperymencie czynnym przeprowadzonym na samochodzie Fiat Punto z 5-biegowa skrzyniq biegów. Opisana metoda może stanowić uzupetnienie istniejacych systemów pokładowych $w$ samochodach o uszkodzenia mechaniczne zespołu napędowego pojazdu. Procedura może zostać rozszerzona o uszkodzenia przekładni głównej, mechanizmu różnicowego, przegubów, tożysk oraz uszkodzenia zaworów wylotowych silnika i uszczelki glowicy silnika.

Stowa kluczowe: model diagnostyczny, sygnat przyspieszenia drgań, zużycie skrzyni biegów, diagnostyka pokładowa, identyfikacja modelu

\section{INTRODUCTION}

Toothed gear modelling was the subject of several work, both monographs and scientific papers. Various methods of toothed gear modelling are presented, and their usefulness for design that is aimed at the maintenance is estimated in (Dąbrowski et al. 2000). The synthesis of the kinematic models is presented in works (Müller 1986, Wilk 1981, Klekot 1992). Modelling of gearboxes is shown in several references (Fakhfakh et al. 2005, Endo et al. 2007, Nagwa et al. 2008, Tian et al. 2009). However, it is not possible to treat each subassembly of an automobile separately, since their interaction occurs all the time. Simultaneously, we are de- aling with a continuous change of the rotational speed and engine load. Thus, the cyclostationary and transient processes occur in the vehicle drive system.

The dynamic model of the automobile gearbox is even more complex since the clutch transfers vibrations from the automobile engine and additional dynamic excitations from the foundation are influencing the gearbox component elements, which makes the model strongly non-linear (Fig. 1).

The investigations performed on real objects as well as the simulations allowed us to formulate several conclusions concerning the influence of the gearbox operation on the vibroacoustic signal generated by it. Components related to individual cylinder operation are clearly seen, and their fre-

\footnotetext{
* Faculty of Mechanical Engineering, Technical University of Radom, Radom, Poland; iwona.komorska@pr.radom.pl
} 


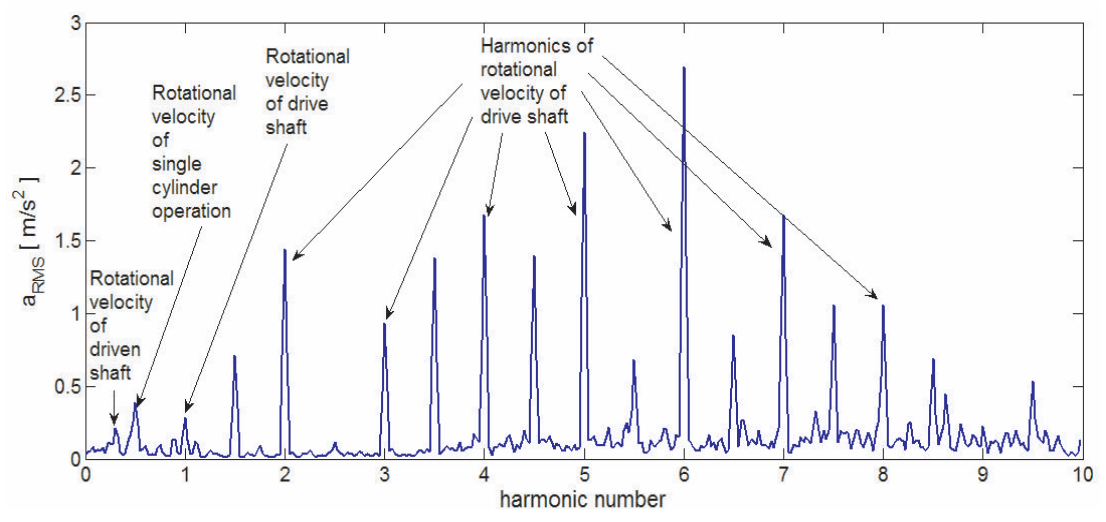

Fig. 1. Average spectrum of gearbox vibration acceleration (low frequencies)

quencies for the 4-cylinder engine are determined by the equation:

$$
f_{c}=k \cdot \frac{1}{2} \cdot f_{0}, k=1,2,3 \ldots
$$

where $f_{0}$ - basic frequency (shaft rotational speed).

The shaft rotational speed has also an influence on the vibration signal amplitudes. The diagnostic procedure of the gearbox can be done automatically during driving. In such a case, the reference model must be 'a priori' defined and identified in an adaptive way - on the grounds of the recorded and averaged vibration signal for the determined shaft rotational speed of the new gearbox. After each repair of the drive system (not only the gearbox) the reference model must be identified anew. To achieve this the vibration signal is being pre-processed. At first resampling occurs, it means the transfer from the time domain to the crankshaft rotation angle domain. Then, the signal is filtered, synchronously averaged, and eventually undergoes decimation. To simplify this procedure as much as possible, the model is identified and diagnosed for the determined rotational speed, it means when the automobile is driving with the determined speed without abrupt load changes.

\section{VIBRATION SIGNAL MODELLING}

\subsection{Train of harmonics}

The basic dominant aspects of the vibroacoustic signal are the tooth mesh frequency and its multiples.

$$
f_{z}=f_{0} \cdot z
$$

where:

$f_{0}-$ basic frequency (shaft rotational speed),

$z$ - teeth number of the driving wheel.
Successive pairs of teeth entering into contact can be treated as the impulse forces for signal modelling and are described by the pulse train (Dąbrowski 1993):

$$
p(t)=p_{z}\left(N, z_{1}, \ldots z_{n}\right) \cdot \delta\left(t-\frac{1}{f_{z}}\right)
$$

where:

$$
\begin{aligned}
p_{z}- & \text { function dependent on the load } N \text {, and parame- } \\
& \text { ters } z_{1}, \ldots z_{n}, \text { which are e.g. production accuracy, } \\
& \text { teeth wearing rate, assembling accuracy, place } \\
& \text { of measuring etc., } \\
\delta- & \text { Dirac's delta, } \\
f_{z}- & \text { tooth mesh frequency. }
\end{aligned}
$$

In real systems the Dirac's delta in an impulse of limited amplitude and the signal spectrum is expressed by the following formula:

$$
P(\omega)=P_{z}(\omega) * H_{z} \cdot \delta\left(\omega-\omega_{z}\right)
$$

where:

$$
\begin{aligned}
P_{z}(\omega) & - \text { Fourier transform of the function, } \\
H_{z} & - \text { system transmittance, } \\
\omega_{z} & - \text { tooth mesh frequency. }
\end{aligned}
$$

As a result of teeth cooperation, the coefficient of teeth stiffness changes with time, which causes a formation of side bands around the tooth mesh frequency and its harmonics (the second group of spectrum components). When the teeth begin to wear out and inter-teeth clearance increases, the amplitude of these components also increases.

The third group of the vibroacoustic signal components of the gear constitutes the harmonics of the basic frequency (shaft rotational speed). Numerous observations (Dąbrowski et al. 2001, Komorska 1999) indicate that, as the gear is wearing out, all production and assembling deviations are increasing these very components.

The gearbox in the automobile works under dynamic conditions of misalignment and unbalancing; therefore, 
when the toothed gear is wearing out, it is increasing the occurrence of the harmonic rotational speed series of the crankshaft as expected.

The mathematical model of the gearbox is highly nonlinear. Wearing out of the gearbox causes qualitative and quantitative changes in the time waveform, the spectrum of vibrations, and the acoustic pressure signals. Two various approaches to the gearbox vibroacoustic signal are possible. Either we can look for nonlinear model coefficients or we can write the linear model introducing into it, in an evident way, components related to wear and defects.

The first approach is difficult for an application due to problems with the identification of such a model, which requires an active experiment making the model unique for only a single gearbox specimen. In the second method, the nonlinear model undergoes linearization, since nonlinear effects are substituted by new components appearing in the signal at the determined defects. The remaining unidentified components occur in the description as the model structural error.

In accordance with the above, expanding model (Dabrowski 1993) for the gearbox under maintenance conditions, we obtain the model of the vibroacoustic signal in the time domain:

$$
\begin{aligned}
& S_{t}\left\{x_{j}(t, \Theta, r, n)\right\}= \\
& =p_{z}\left(t, \ldots z_{i}\right) \cdot \delta\left(t-\frac{k}{f_{z}}\right) * h_{z j}\left(t-\tau, \ldots z_{i}\right)+ \\
& +p_{s b}\left(t, \ldots z_{i}\right) \cdot \delta\left(t-\left(\frac{k}{f_{z}} \pm \frac{n}{f_{0}}\right)\right) * \\
& * h_{s b j}\left(t-\tau, \ldots z_{i}\right)+p_{0}\left(t, \ldots z_{i}\right) \cdot \delta\left(t-\frac{m}{f_{0}}\right) * \\
& * h_{0 j}\left(t-\tau, \ldots z_{i}\right)+\varphi_{j}\left(t, \ldots z_{i}\right)+\psi_{j}
\end{aligned}
$$

and in the frequency domain:

$$
\begin{aligned}
& S_{\omega}\left\{X_{j}(\omega, \Theta, r, n)\right\}= \\
& =P_{z}\left(t, \ldots z_{i}\right) \cdot \delta\left(\omega-k \omega_{z}\right) \cdot H_{z j}\left(\omega, \ldots z_{i}\right)+ \\
& +P_{s b}\left(\omega, \ldots z_{i}\right) \cdot \delta\left(\omega-\left(k \omega_{z} \pm n \omega_{0}\right)\right) . \\
& \cdot H_{s b j}\left(\omega, \ldots z_{i}\right)+P_{0}\left(\omega, \ldots z_{i}\right) \cdot \delta\left(\omega-m \omega_{0}\right) \\
& \cdot H_{0 j}\left(\omega, \ldots z_{i}\right)+\Phi_{j}\left(\omega, \ldots z_{i}\right)+\Psi_{j}
\end{aligned}
$$

where:

$$
\begin{aligned}
S_{t}, S \omega-\text { average operators in the time and } \\
\text { frequency domain, }
\end{aligned}
$$

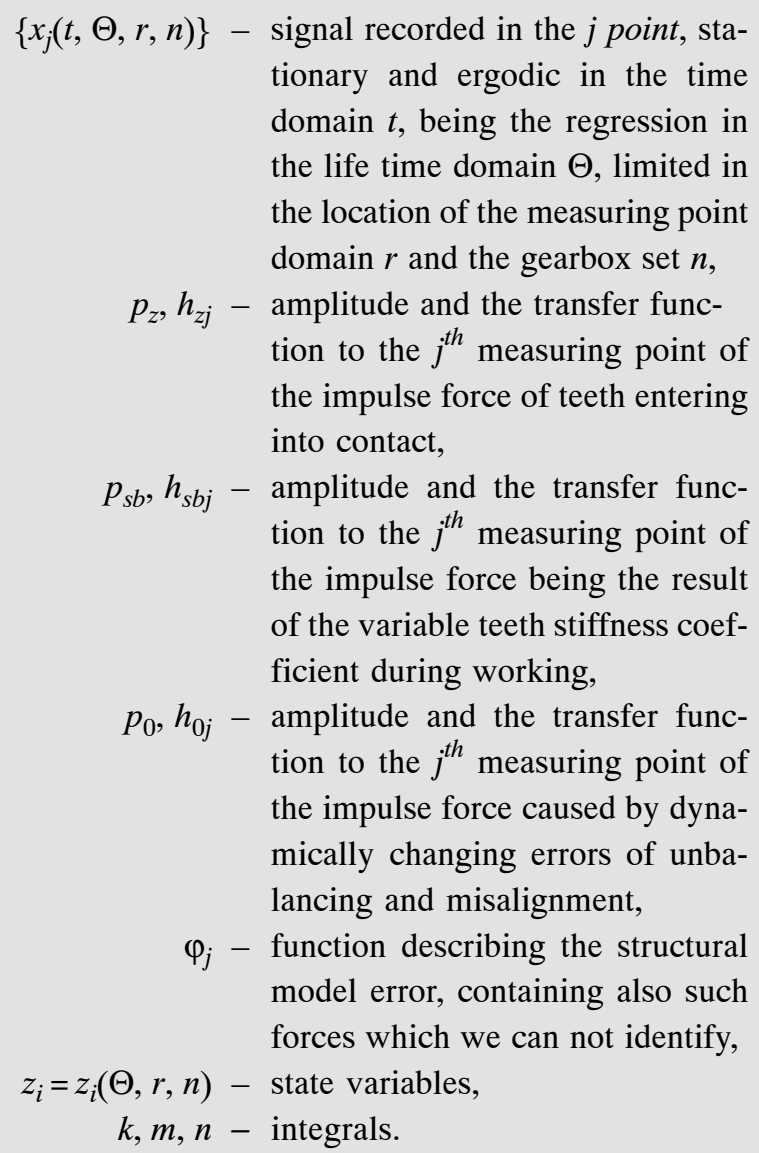

\subsection{ARMA model}

When the impulse forces as well as the character of the signal responses are known and the signal has random noise features (Janiszowski 2002), it is better to chose the Auto Regressive Moving Average model structure (ARMA), which contains both the influence of the exciting signal $x$ and components containing past output values. It is described by the differential equation:

$$
\begin{aligned}
& y(k)=b_{0} x(k)+\ldots+b_{n} y(k-n)-a_{1} y(k-1)- \\
& -\ldots-a_{n} y(k-n)+\varepsilon(k)= \\
& =\sum_{i=1}^{n} b_{i} x(k-i)-\sum_{i=1}^{n} a_{i} y(k-i)+\varepsilon(k)=v(k) \theta
\end{aligned}
$$

where:

$$
\begin{aligned}
& v(k)=[x(k), x(k-1), \ldots, x(k-n), \\
& -y(k-1)-y(k-2)-, \ldots,-j(k-n)] \\
& \theta=\left[b_{0}, \ldots, b_{n}, a_{1}, \ldots, a_{n}\right]^{\prime}
\end{aligned}
$$

Number $n$ of time instants is the order of the model. Equation (7) can be expressed in another form:

$$
y(k)=B(z) x(k)+A(z) y(k)+\varepsilon(k)
$$


where:

$$
\begin{aligned}
& A(z)=-a_{1} z^{-1}-a_{2} z^{-2}-\ldots-a_{n} z^{-n} \\
& B(z)=b_{0}+b_{1} z^{-1}+b_{2} z^{-2}+\ldots+b_{n} z^{-n}
\end{aligned}
$$

The ARMA structure corresponds to the block diagram of the digital mixed filter. The block diagram of the ARMA model is presented in Figure 2.

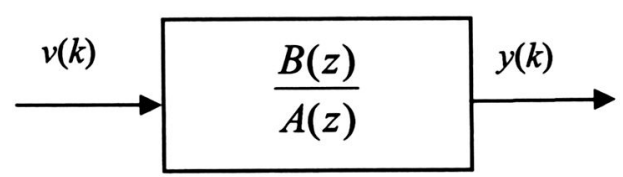

Fig. 2. Model of the ARMA structure

Before identification the signal must be properly prepared by:

- removal of constant components and trends,

- filtration in order to select the characteristic frequency range,

- determination of the autocorrelation function or synchronous averaging,

- decimation.

\subsection{The wavelet model}

The wavelet transform enables the linear signal decomposition by means of an arbitrary base function characterised by the finished and short interval which assumes non-zero values. If $\psi(t)$ is the mother wavelet then the daughter wavelet has a form (Białasiewicz 2004):

$$
\psi_{a, b}(t)=\frac{\psi(t-b)}{a}
$$

where $a$ is a scale coefficient and $b$ is a shifting.

By changing parameters $a$ and $b$ the wavelet family can be formed.

The continuous wavelet transform is easy for interpretation, however, in practical applications it is better to use the discrete wavelet transform. As a result of the quantization of parameters a and $\mathrm{b}$, the following equation equivalent is obtained:

$$
\psi_{m n}(t)=2^{-m / 2} \psi\left(2^{-m}\left(t-2^{m} n\right)\right)
$$

where $m$ is a discrete scale coefficient and $n$ discrete shifting.

The inverse discrete wavelet transform allows for the signal reconstruction and is described

$$
f(t)=\sum_{m, n}\left(f, \psi_{m, n}\right) \psi_{m, n}=\sum_{m} \sum_{n} d_{m}[n] \psi_{m, n}
$$

where $d_{m}[n]=\left(f, \psi_{m, n}\right)$ denotes wavelet coefficients and $\psi_{m, n}$ wavelets of the frequency scale coefficients $m$ and displacement in time $n$.

On the grounds of wavelet coefficients as a scale coefficient and displacement in time (or a shaft rotation angle) function signal reconstruction can be performed. Thus, the model identification can be reduced to the detection of coefficients $d_{m}[n]$.

Since in case of random signals can be many wavelet coefficients, their compression can be performed taking into account only the most energetic.

\section{INVESTIGATIONS}

In order to investigate an influence of the wear of the gearbox teeth on the vibroacoustic signal active experiments were carried out for the following states:

1) gearbox in good technical condition;

2) teeth of a drive wheel of the $5^{\text {th }}$ gear slightly worn at $1 / 3$ of a diameter; and,

3 ) teeth of a drive wheel of the $5^{\text {th }}$ gear significantly worn at $1 / 3$ of a diameter (Fig. 3).

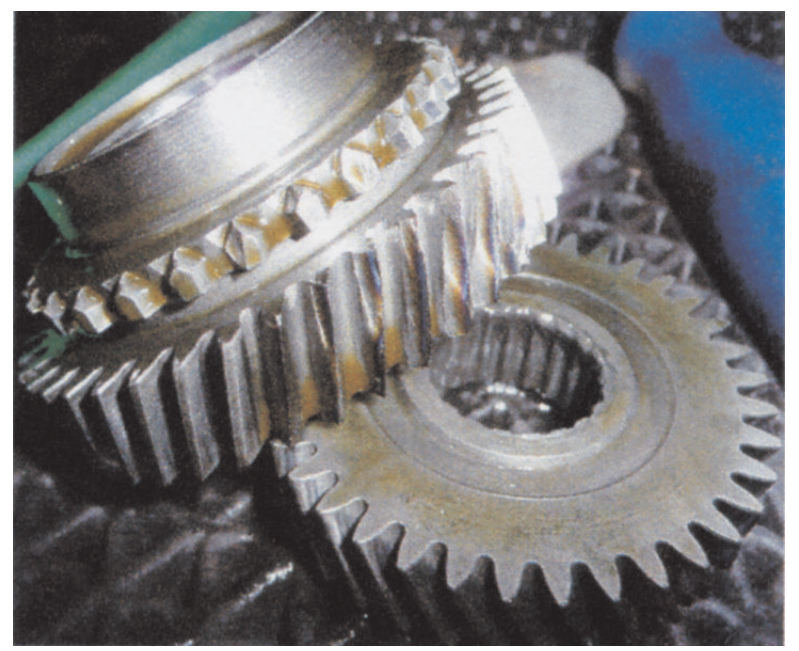

Fig. 3. Worn teeth of the gearbox

Accelerations of the gearbox vibrations were processed by means of the Bruel \& Kjaer DeltaShear sensors, IEPE No. 4514 of a work temperature from -40 to $85^{\circ} \mathrm{C}$, fixed by a screw joint. An additional signal of the crankshaft position for vibration signal synchronisation was recorded. Signals of 1-minute duration were recorded during driving with a constant speed. Small speed fluctuations were eliminated during further analysis.

Figure 4 presents the comparison of spectra of the vibration accelerations measured on the gearbox housing for the different gearbox states. 

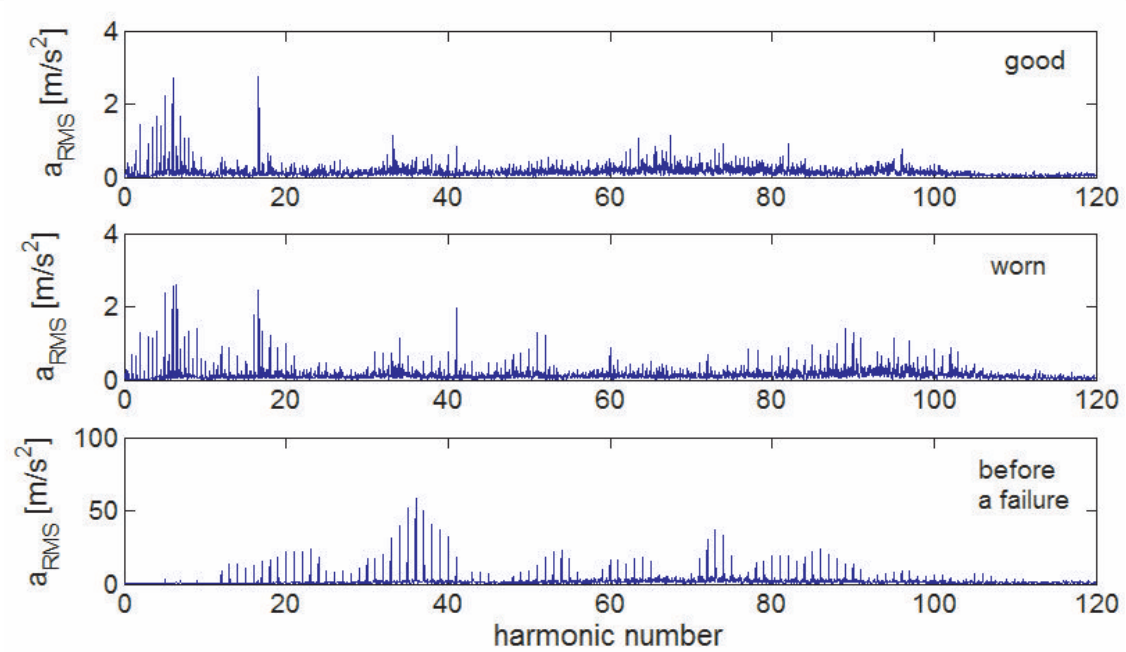

Fig. 4. Spectrum of the acceleration of the gearbox vibrations for teeth in good technical condition, for slightly worn at $1 / 3$ of the diameter and for significantly worn (just before a failure)

In accordance with expectations, the worn teeth passing in the gearbox causes quantitative and qualitative changes of frequency characteristics of the vibration signal. The third case, which is significant teeth wearing, does not require any complicated analysis. The vibration amplitude increases nearly 20 times, and the noise caused by the gearbox is audible in the driver's seat. The defect generates a sequence of harmonic components of the crankshaft rotational speed in which even the tooth mesh frequency is lost ( $\mathrm{x} 41)$. Harmonics are clearly amplified by the system's natural frequencies.

The case of the initial wearing of teeth deserves more attention. Periodical, small increases of the signal vibration amplitude are seen in the time diagram, while more harmonic components appear in the spectrum.

Diagnostics can also be performed based on the time waveform. In order to eliminate random disturbances, the synchronous averaging of 10 engine work cycles were carried out using the crankshaft position signal. Figure 5 presents the averaged time waveforms of the accelerations of the gearbox vibrations for the gearbox in good technical condi- tion, for initially worn, and just before a failure during two engine crankshaft rotations.

The third case illustrates the distinct increase of vibration amplitudes during worn teeth passing through the gearbox.

The wear of the gearbox teeth is also distinctly seen when the signal is decomposed in the domain of time (angle) and frequency (scale). The results of the wavelet analysis performed for two crankshaft rotations by means of the Morlet wavelet, which is often chosen by researchers (Jin et al. 2000, 2003), at the analysis of gearbox teeth defects, are illustrated in Figure 6.

At initial teeth wear, the components of vibrations appear at the small scales, which is characteristic for impulse forces caused by the defects of individual teeth. The increased amplitude zone occurs for wavelets of scales 56-90 and at a local maximum for the scale coefficient 83 . This range corresponds to the previously analysed harmonics range. The second zone constitutes large scales characterising low-frequency vibrations that originate from shaft rotational speeds and their consecutive harmonics.
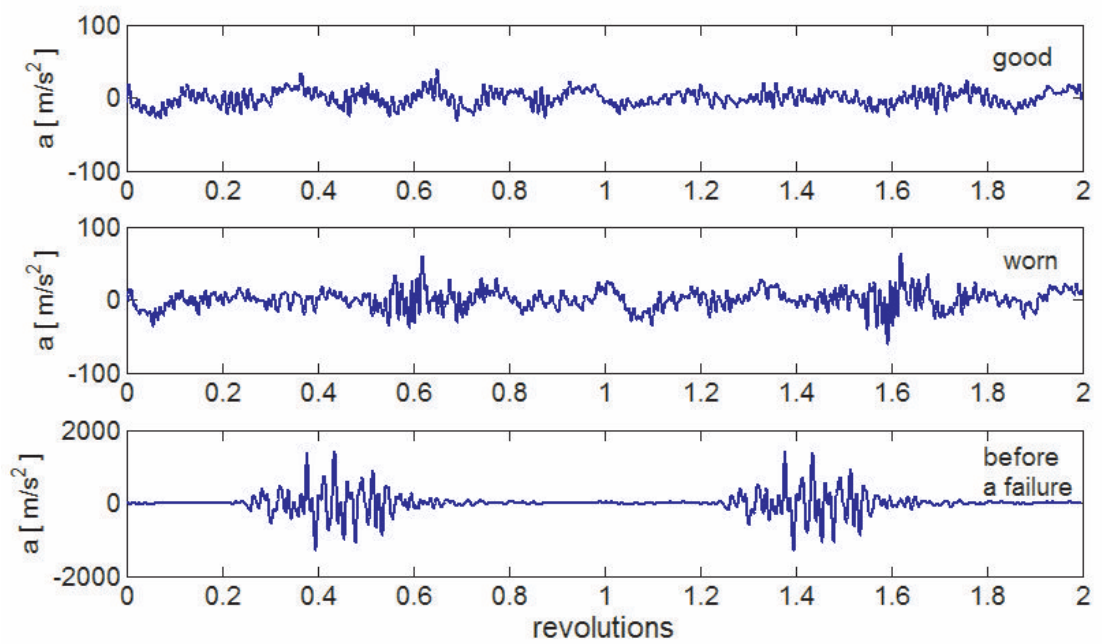

Fig. 5. Synchronously averaged time waveforms at a speed of $3000 \mathrm{rpm}$ 
a)

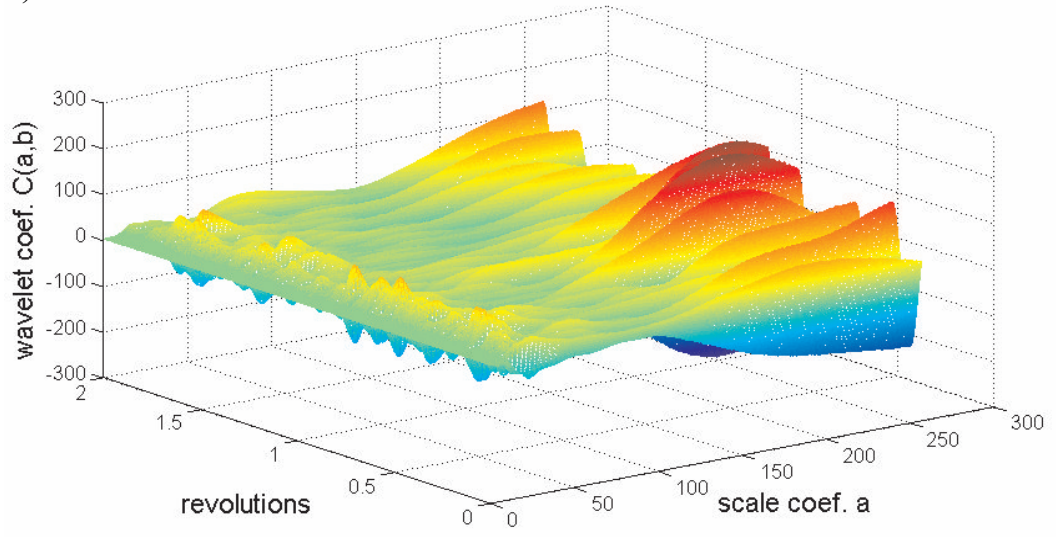

b)

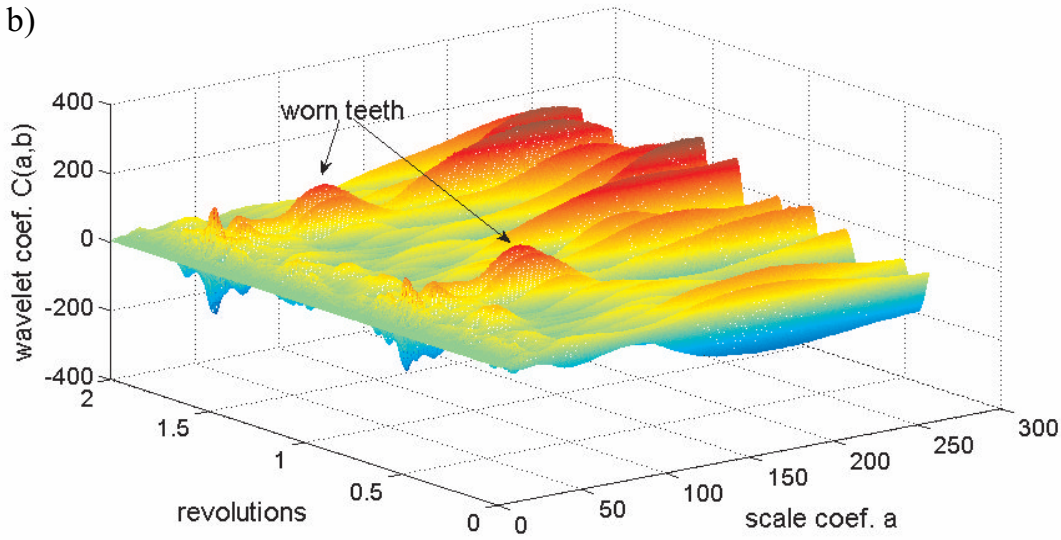

c)

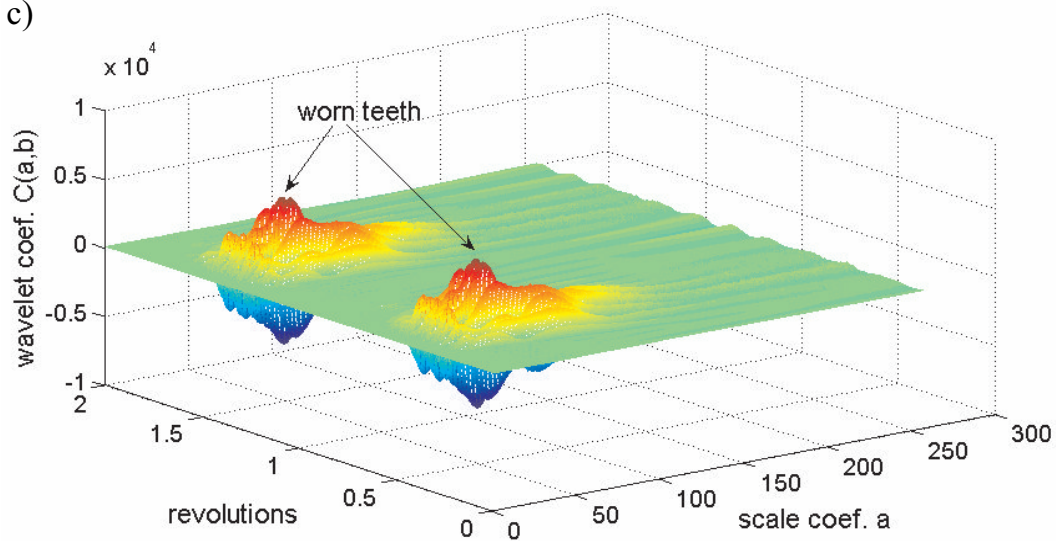

Fig. 6. Results of the analysis of the gearbox vibrations signal, obtained by means of the continuous wavelet transform for three states: a) toothed wheels in good technical condition; b) initial wear of teeth; c) significant wear of teeth - just before failure

\section{VERIFICATION OF THE MODEL}

\subsection{Train of harmonics verification}

Amplitudes of the harmonic components of the vibration signal of the gearbox in good technical condition and with the initial wear at $1 / 3$ of the diameter measured during operation are compared in Figure $7 \mathrm{a}$. In Figure $7 \mathrm{~b}$ there is a list of amplitudes for the gearbox with the initial wear and just before the failure.

The basic component (crankshaft rotational speed) and its successive eight harmonics play a large part in the signal spectrum, but their amplitude does not change even with significant wear of the gearbox. However, a clear amplitude increase is seen in the $9^{\text {th }}$ to $30^{\text {th }}$ harmonics of the crankshaft rotational speed.

Assuming an increase of the harmonic components of the rotational speed as a symptom of the gearbox wear, the simple diagnostic measure in a form of the sum of these amplitudes can be formulated.

$$
H=\sum_{i=9}^{30} H(i)
$$

where $H(i)$ - amplitude of the $i^{\text {th }}$ harmonic of the crankshaft rotational speed. 
a)

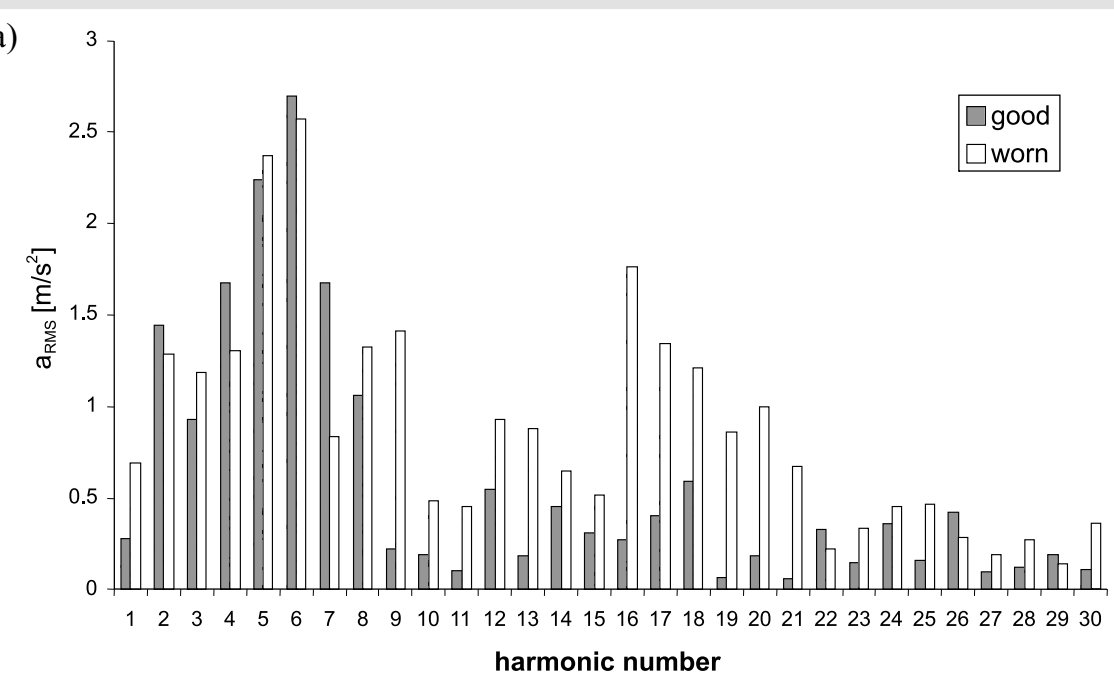

b)

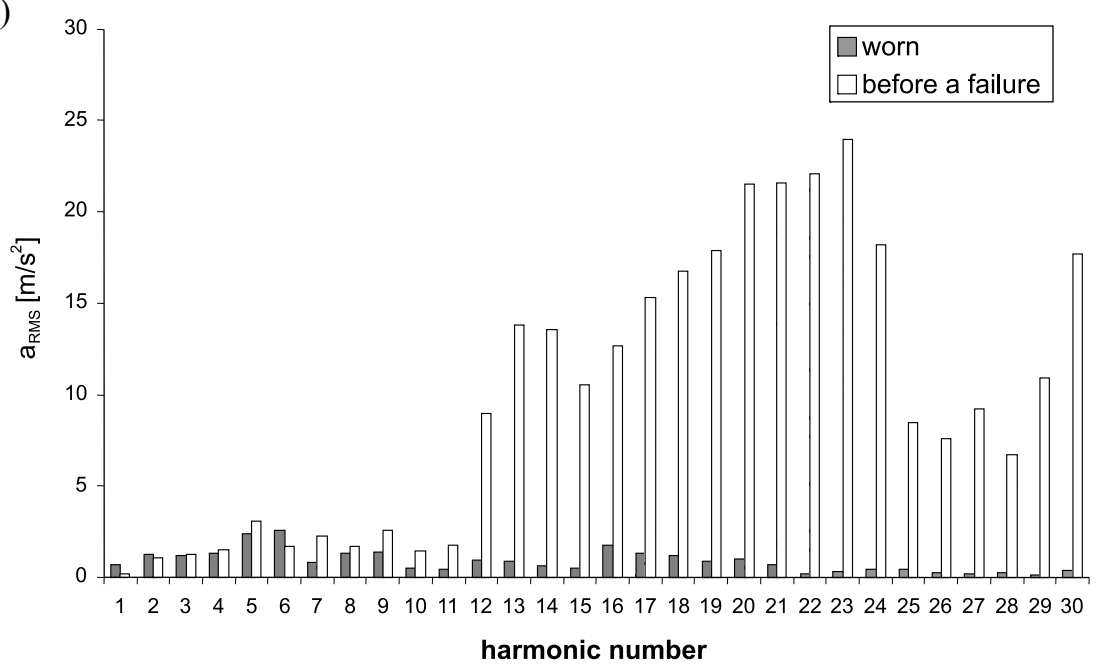

Fig. 7. List of the amplitudes of vibration accelerations for successive harmonics of the engine rotational speed:

a) for the gearbox in good technical condition and with initially worn teeth; b) for the gearbox with initially worn teeth and just before a failure

The measures defined by Eq. (16) for the gearbox in good technical condition, for the gearbox with worn teeth, the gearbox just before a failure, and for the new pair of toothed wheels for three rotational speeds $(2000,3000$ and $4000 \mathrm{rpm}$ ) are listed in Table 1. At the initial teeth wear, the measure was increased by approximately 2.7 times for 2000 and $3000 \mathrm{rpm}$ and by 1.5 times (the least) for $4000 \mathrm{rpm}$.

\section{Table 1}

Measures of the teeth wear of the gearbox calculated based on the sum of the harmonics for various wear stages at three rotational speeds

\begin{tabular}{|c|c|c|c|c|}
\hline $\begin{array}{c}\text { Rotational } \\
\text { speed } \\
\text { of the } \\
\text { crankshaft }\end{array}$ & $\begin{array}{c}\text { Good } \\
\text { gearbox }\end{array}$ & $\begin{array}{c}\text { Initial } \\
\text { wear }\end{array}$ & $\begin{array}{c}\text { Before } \\
\text { failure }\end{array}$ & $\begin{array}{c}\text { New } \\
\text { gearbox } \\
\text { (after } \\
\text { replacement) }\end{array}$ \\
\hline $2000 \mathrm{rpm}$ & 1.87 & 5.01 & 115.25 & 2.31 \\
\hline $3000 \mathrm{rpm}$ & 5.49 & 14.88 & 283.21 & 5.72 \\
\hline $4000 \mathrm{rpm}$ & 18.77 & 27.45 & 452.75 & 13.95 \\
\hline
\end{tabular}

\subsection{ARMA model verification}

Let us perform the parametric identification for the timewaveform of the gearbox vibration signal of the drive system in good technical condition. This signal should be prepared by filtering out high-frequencies (higher than 70 times the crankshaft frequency) and by synchronous averaging. Then, the autocorrelation function must be determined. Decimation was also applied since the signal was over-sampled and the model identification would require too many, rather useless, coefficients.

The model quality assessment is done on the basis of the following indices: Akaike's Information Criterion AIC, Final Prediction Error FPE, and Fit (Komorska 2011). On the basis of the model assessment indices, it can be assumed that the ARMA model with $10 a$ parameters and $8 b$ parameters is satisfactory. The comparison of the recorded vibration signal with the ARMA model output is presented in Figure 8.

The comparison of the autocorrelation function of the reference model vibration signal of the gearbox, with the autocorrelation function of signal recorded for the gearbox with initial worn teeth, is presented in Figure 9. 


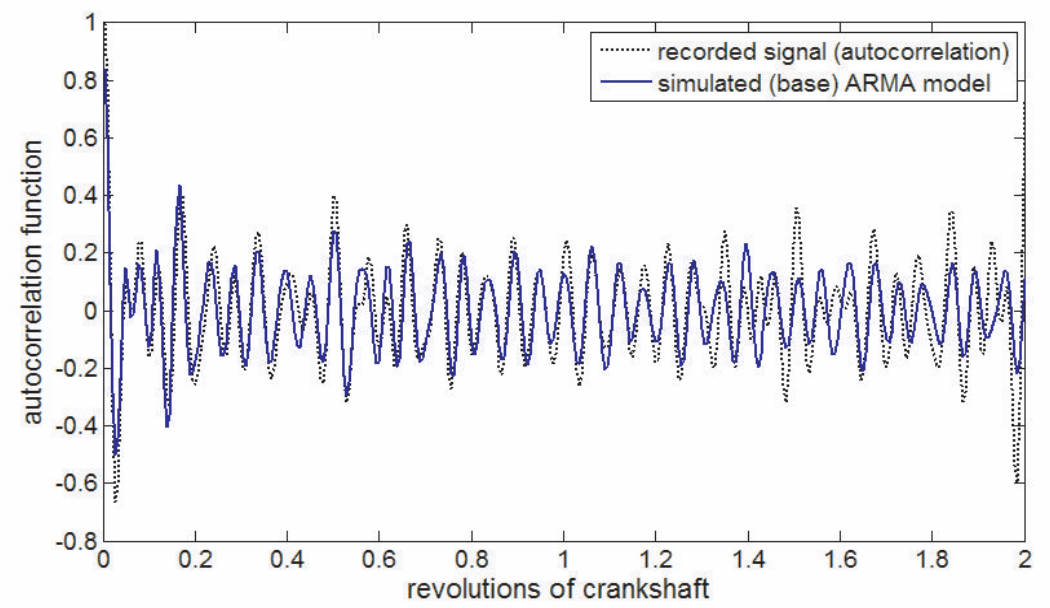

Fig. 8. Identification of the ARMA reference model of the gearbox vibration signal

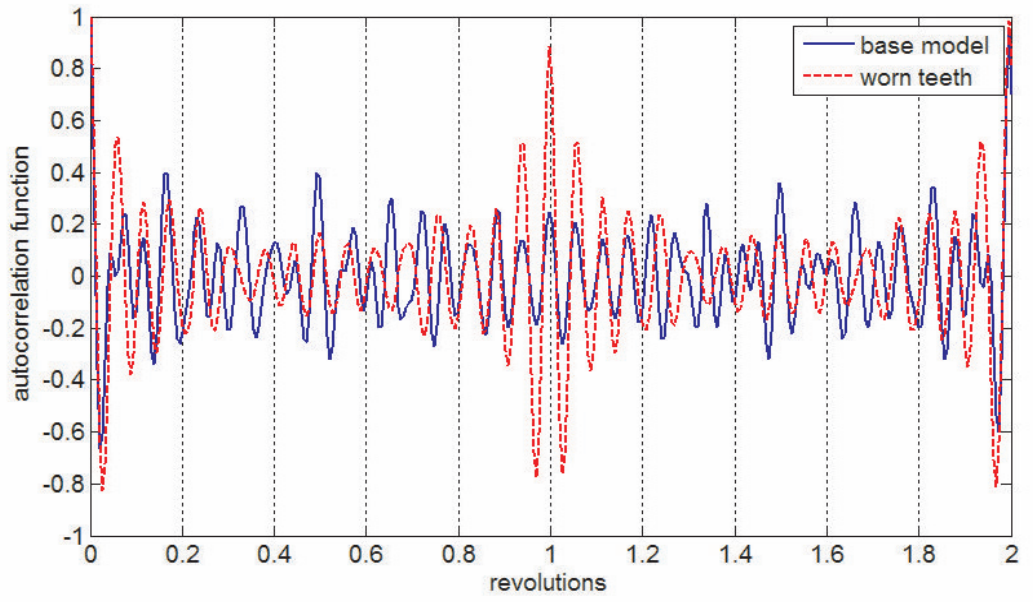

Fig. 9. Comparison of the reference model and the signal for the defective gearbox

In the case of statistic models the autocorrelation function waveform for various degrees of toothed wheel wearing out is similar because only the signal modulation is discovered. The selected measures of the signal and the dimensionless coefficients determined for the reference mo- del and for the worn out gearbox as well as the relative changes of these measures are listed in Table 2. The highest sensitivity to wearing out shows the Peak-to-Peak value and the dimensionless coefficients (Peak coefficient and Impulse coefficient).

Table 2

Signal measures of the teeth wear of the gearbox for the reference model and the worn gearbox at $3000 \mathrm{rpm}$

\begin{tabular}{|l|c|c|c|c|}
\hline \multicolumn{1}{|c|}{ Signal measure } & Equation & Reference model & Defective gearbox & Measure change \\
\hline Peak-to-peak value & $x_{P P}=\max |x(t)>0|+\min |x(t)<0|$ & 0.74 & 1.66 \\
\hline Average value & $\bar{x}=\frac{1}{N} \sum_{k=1}^{N}|x(k)|$ & 0.14 & 0.18 \\
\hline Square value & $\psi^{2}=\frac{1}{N} \sum_{k=1}^{N} x^{2}(k)$ & 0.04 & 0.06 & 1.28 \\
\hline RMS value & $x_{R M S}=\sqrt{\frac{1}{N} \sum_{k=1}^{N} x^{2}(k)}$ & 0.19 & 0.25 & 1.31 \\
\hline Peak coefficient & $C=\frac{x_{P P}}{x_{R M S}}$ & 3.80 & 6.64 & 1.75 \\
\hline Impulse coefficient & $W I=\frac{x_{P P}}{\bar{x}}$ & 5.11 & 9.39 & 1.84 \\
\hline
\end{tabular}




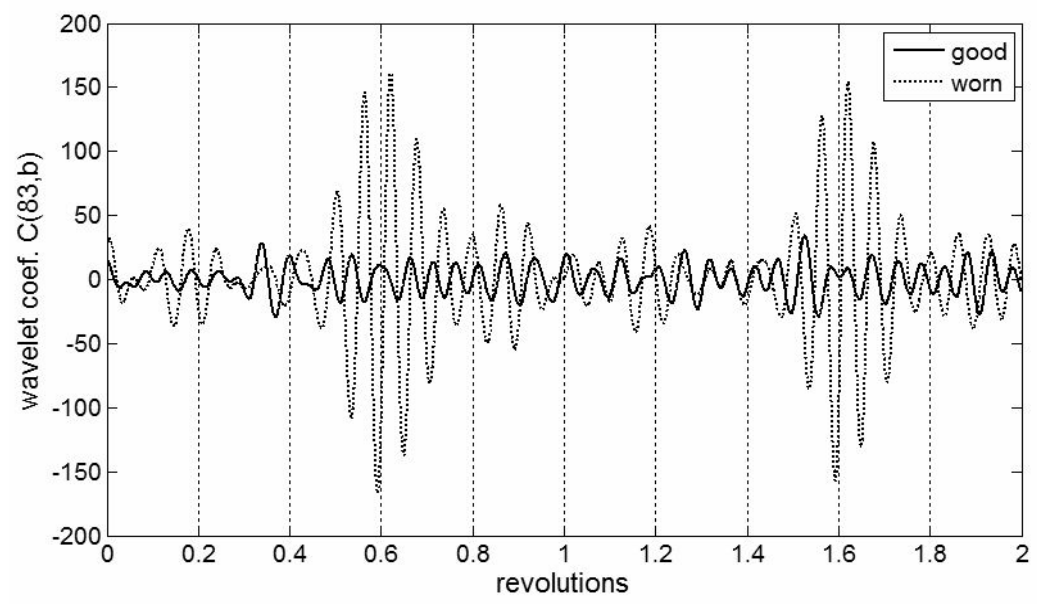

Fig. 10. Wavelet decomposition of the vibration signal for the scale coefficient 83

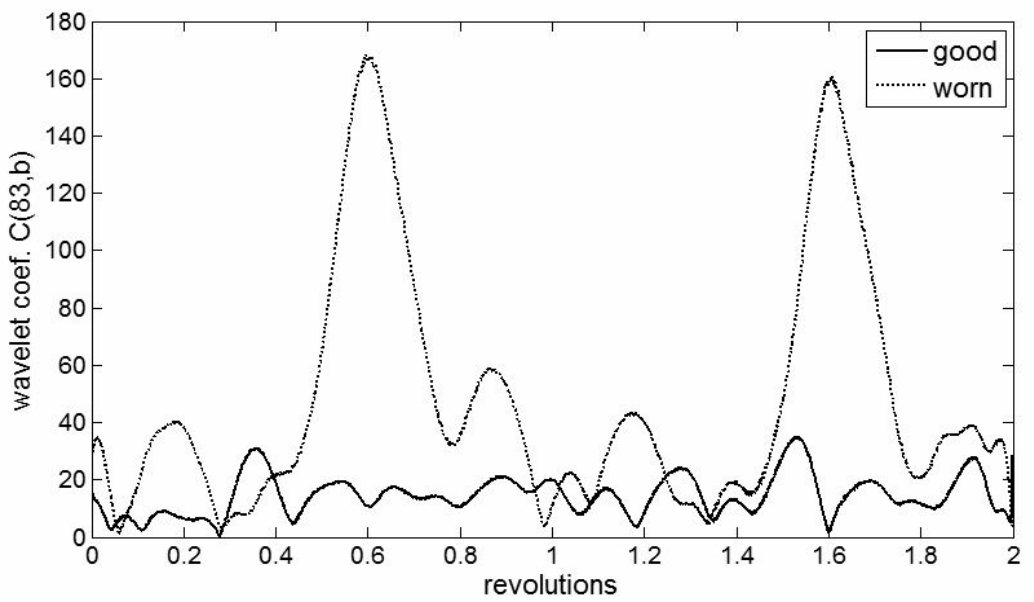

Fig. 11. Envelopes of the signals shown in Figure 10

\subsection{Wavelet model verification}

Figure 10 presents the wavelet decomposition for the scale coefficient 83 of the vibration signal of the gearbox in good technical condition and the gearbox with worn teeth, while Figure 11 presents envelopes of these signals.

Based on the signal envelope the average value can be determined according to the following equation for diagnostic aims:

$$
a_{w a v}=\frac{1}{T} \int_{0}^{T} a_{e n v}(t) d t
$$

where:

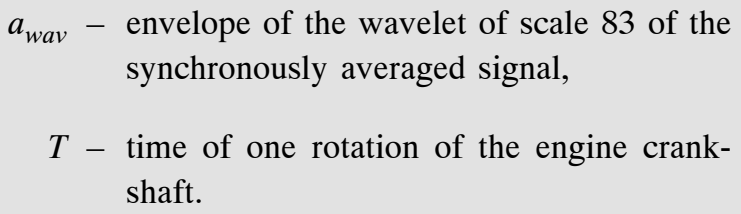

Measures calculated according to Eq. (17) for various rotational speeds and for various wear degrees of toothed wheels are listed in Table 3.

Table 3

Measures of the teeth wear of the gearbox calculated based on the wavelet envelope for various wear stages at three rotational speeds

\begin{tabular}{|c|c|c|c|c|}
\hline $\begin{array}{c}\text { Rotational speed } \\
\text { of the crankshaft }\end{array}$ & Good gearbox & Initial wear & Before failure & $\begin{array}{c}\text { New gearbox } \\
\text { (after replacement) }\end{array}$ \\
\hline $2000 \mathrm{rpm}$ & 6.85 & 13.42 & 387.43 & 5.94 \\
\hline $3000 \mathrm{rpm}$ & 18.31 & 47.92 & 563.58 & 14.55 \\
\hline $4000 \mathrm{rpm}$ & 24.21 & 54.69 & 685.02 & 24.20 \\
\hline
\end{tabular}




\section{CONCLUSIONS}

Three ways of the gearbox vibration signal modelling and identification were presented. Each of them separately or all of them jointly can be implemented in the on-board automobile system during its normal maintenance. The model identification program as well as diagnostics of the gearbox condition can be done automatically.

All of the presented measures of the wear of the gearbox toothed wheels are based on the signal modulation and increase of the amplitude of consecutive harmonics of the engine rotational speed, which appear when worn teeth enter into tooth contact. This is clearly seen in the time waveform of the gearbox housing vibrations, its autocorrelation function and even more precisely in the time-frequency distribution carried out by means of the continuous wavelet analysis. On this basis, simple measures of the wear, which allow for the diagnosing of this type of defect, can be formulated. They are based on the detection of harmonics and on the envelope of the processed signal. Random errors are impossible in this method because the analysis is carried out on the synchronously averaged signals.

We can conclude from the investigations that, for the given gearbox type and for the analysed fifth gear, the highest amplitudes coincide with the $16^{\text {th }}$ and $17^{\text {th }}$ harmonics, which is related to the system's natural frequencies. That is the cause of the analysed scale in the wavelet analysis. For another drive system, another gear, and a different automobile, the maximum of the harmonics of worn teeth can occur in a different place of the spectrum. The problem can be solved by looking for such frequencies in an adaptive way.

\section{References}

Białasiewicz J.T. 2004, Falki i aproksymacje, 2nd ed. WNT, Warszawa. Dąbrowski Z. 1993, The Relationship Signal-Mathematical Model as the Basis of Processing System, Inter-Noise'93, Leuven-Belgium, pp. 901-904.
Dąbrowski Z., Komorska I., Puchalski A. 2001, Diagnozowanie błędów wykonania i montażu układów wirujacych. Wyd. Instytutu Technologii Eksploatacji, Radom.

Dąbrowski Z., Radkowski S., Wilk A. (eds) 2000, Dynamika przekładni zębatych. Badania $i$ symulacja $w$ projektowaniu eksploatacyjnie zorientowanym, Wyd. Instytutu Technologii Eksploatacji, Radom.

Endo H., Randall R.B. 2007, Enhancement of autoregressive model based gear tooth fault detection technique by the use of minimum entropy deconvolution filter, Mechanical Systems and Signal Processing, 21, pp. 906-919.

Fakhfakh T., Chaari F., Haddar M. 2005, Numerical and Experimental Analysis of a Gear System with Teeth Defects, International Journal of Advanced Manufacturing Technology, 25, pp. 542-550.

Janiszowski K. 2002, Identyfikacja modeli parametrycznych $w$ przykladach, Akad. Oficyna Wydawnicza EXIT, Warszawa.

Klekot G. 1992, Simplified kinematic model of the spur gear with involute teeth elaborated for analysis of the gear vibroactivity, Machine Vibration, manuscript MV/9216, Springer Verlag, London.

Komorska I. 1999, Badanie wplywu błędów montażowych na dynamike szeregowych układów przeniesienia mocy, Warszawa, Rozprawa doktorska.

Komorska I. 2011, Vibroacoustic diagnostic model of the vehicle drive system, Wyd. Instytut Technologii Eksploatacji, Radom.

Komorska I. 2011, Model of the vibration signal of the vehicle drive system as a diagnostic tool, Zagadnienia Eksploatacji Maszyn, 1(165), vol. 46.

Lin J., Qu L. 2000, Feature Extraction Based on Morlet Wavelet and It's Application for Mechanical Fault Diagnosis, Journal of Sound and Vibration, 234(1), pp. 135-148.

Lin J., Zuo M.J. 2003, Gearbox Fault Diagnosis Using Adaptive Wavelet Filter, Mechanical Systems and Signal Processing, 17(6), pp. 12591269.

Müller L. 1986, Przektadnie zębate - dynamika, WNT, Warszawa.

Nagwa A., Nabil H., Magdy A. 2008, Dynamic Modeling of Vehicle Gearbox for Early Detection of Localized Tooth Defect, SAE Technical Paper, 2008-01-2630.

Tian Z., Zuo M.J., Wu S. 2009, Crack propagation assessment for spur gears using model-based analysis and simulation, Journal of Intelligent Manufacturing.

Wilk A. 1981, Wplyw parametrów technologicznych i konstrukcyjnych na dynamike przektadni zębatych o zębach prostych, Zeszyty Naukowe Pol. Śląskiej, Mechanika, z. 72, Gliwice, Ph.D. Thesis. 